\title{
Penerapan Model Pembelajaran Guided Discovery Dengan Menggunakan Media Mindjet Mind Manager Untuk Meningkatkan Aktivitas dan Hasil Belajar Kimia Siswa Kelas X IPA SMA Bahrul Maghfiroh Malang
}

\author{
Wilyati Agustina Bangun \\ Program Studi PJKR IKIP Budi Utomo Malang \\ Jalan Simpang Arjuno 14b Malang \\ email:wilyanti_b@yahoo.com \\ Moh. Zaini \\ Program Studi PJKR IKIP Budi Utomo Malang \\ Jalan Simpang Arjuno 14b Malang \\ email: pojur_zen@yahoo.com
}

\begin{abstract}
Difficulties faced by students about the chemistry lesson, causing students to be passive and low impact on student learning outcomes. Therefore we need a method and model of teaching, so that students are able to discover the concepts, principles through his own mental process. The learning model used is the Guided Discovery, -which give maximum freedom to the students to develop creative thinking and motor power, while the role of the teacher is limited. This learning model utilizes computer media with Mindjet program mindmanagerr 9, which is connected to the power point and macro flash, making it easier for students to show the concepts of Chemistry abstract becomes more concrete
\end{abstract}

Keywords: application, model guided discovery, mindjet mind manager

Kesulitan yang dihadapi siswa mengenai pelajaran kimia yang menyebabkan siswa bersikap pasif dan berdampak pada rendahnya hasil belajar siswa. Menurut Bagus (2007) kualitas pembelajaran kimia yang masih rendah dapat diamati dari prestasi belajar dan ketuntasan belajar siswa. Berkaitan dengan kualitas hasil belajar siswa, dari hasil diskusi dengan guru bidang studi Kimia Kelas X SMA Bahrul Maghfirroh (SMA Berbasis Pondok Pesantren) pada tanggal 20 September 2015, diketahui bahwa ketuntasan hasil belajar siswa untuk kelas $\mathrm{X}$ dalam mata pelajaran Kimia masih tergolong rendah dengan ketuntasan minimal 65.

Hasil diskusi, refleksi dan keinginan dari guru bidang studi Kimia disepakati bahwa perlu dilakukan suatu tindakan yang dapat memperbaiki proses pembelajaran sehingga terjadi peningkatan hasil belajar. Berdasarkan metodelogi pembelajaran ada dua aspek menonjol yang dapat mempengaruhi ketuntasan hasil belajar siswa, yaitu metode dan media pembelajaran. Adanya suatu metode pembelajaran yang membuat siswa menjadi aktif dan bersemangat dalam pembelajaran sangat penting guna meningkatkan hasil belajar tersebut. Siswa tidak tertarik apabila pelajaran kimia hanya difokuskan dalam materi saja. Namun siswa lebih tertarik apabila penyampaian materi pembelajaran sedikit berbeda dari biasanya. Menurut Rusydie (2011) menangani siswa yang kurang bersemangat dalam proses pembelajaran salah satunya ialah dibutuhkannya suatu pembelajaran yang aktif. 
Guided Discovery adalah salah satu bentuk dari metode discovery learning. Discovery learning merupakan salah satu model instruksional kognitif dari Jerome Brunner yang sangat berpengaruh. Menurut Brunner, discovery learning sesuai dengan pencarian pengetahuan secara aktif oleh manusia dan dengan sendirinya memberikan hasil yang baik. Berusaha sendiri untuk mencari pemecahan masalah serta pengetahuan yang menyertainya akan menghasilkan pengetahuan yang bermakna (Trianto, 2007, dalam Sukmana, 2009: 1).

Salah satu model pembelajaran Discovery learning adalah model pembelajaran Guided Discovery. Guided discovery merupakan metode mengajar yang mengatur pengajaran dimana siswa mampu menemukan konsep-konsep, prinsip-prinsip melalui proses mentalnya sendiri. Pada Guided Discovery siswa diberi kebebasan semaksimal mungkin untuk mengembangkan daya kreativitas dan keinginan-keinginan bergerak yang lebih luas dan bebas sehinga peranan guru dibatasi seminim mungkin. Guru berfungsi sebagai fasilisator dalam Guided Discovery, karena guru bertindak sebagai petunjuk jalan dan membantu siswa agar dapat menggunakan ide, konsep dan ketrampilan yang sudah mereka pelajari sebelumnya menemukan pengetahuan baru. Guided Discovery mampu meningkatkan hasil dan aktivitas belajar IPA pada konsep Alat Indera (Bili, 2015)

Aspek kedua adalah media pembelajaran, media sangat berperan dan membantu guru dalam mencapai tujuan pembelajaran. Media adalah segala sesuatu yang dapat digunakan untuk menyalurkan pesan dari pengirim kepada penerima sehingga dapat merangsang pikiran, perasaan, perhatian dan minat siswa yang menjurus kearah terjadinya proses belajar. Mind Map atau peta pikiran menurut Buzan (2005:4) adalah cara termudah untuk menempatkan informasi ke dalam otak dan mengambil informasi keluar otak. Secara sederhana. Mind Map adalah cara mencatat yang kreatif, efektif, dan secara harfiah akan "memetakan" pikiran-pikiran kita. Guru juga hendaknya mampu menggunakan media pembelajaran yang memanfaatkan media computer sebagai sarana untuk menampilkan konsep-konsep Kimia yang abstrak menjadi lebih kongkret. Penggunaan media khususnya computer dalam pembelajaran sangat memudahkan bagi guru dalam menyajikan materi. Guru dapat memanfaatkan program mindjet mindmanagerr 9 untuk membuat peta pikiran yang mampu menghubungkan dengan program lain, baik power point ataupun macro flash (Digibook Technology, 2008:3-4). Penggunaan Aplikasi Mindjet mind manager mampu meningkatkan hasil belajar siswa sebesar 91,77\% pada materi pokok bahasan Alat Optik (Khoirudin, 2013).

Tujuan Penelitian ini untuk mengetahui bagaimanakah penerapan Model Pembelajaran Guided Discovery dengan menggunakan Media Mindjet Mindmanager dapat meningkatkan aktivitas dan hasil belajar Kimia siswa kelas X IPA SMA Bahrul Maghfiroh Malang? Untuk mencapai tujuan tersebut peneliti menggunakan jenis penelitian tindakan kelas, analisis datanya bersifat siklus. Analisis siklus penelitian tindakan kelas meliputi empat tahap, yaitu: 1) perencanaan, 2) tindakan, 3) observasi, 4) refleksi. Manfaat Penelitian Secara teoritis penelitian ini diharapkan memberikan sumbangan bagi khasanah pengetahuan sebagai cakrawala baru dalam konteks pembelajaran. Secara praktis, bahwa guided discovery adalah salah satu model pembelajaran dimana siswa dapat menemukan konsep-konsep dan prinsip-prinsip melalui proses mentalnya sendiri. Mindjet mindmanager adalah media pembelajaran yang mengasyikan, membantu siswa membuat peta pikiran yang mampu menghubungkan dengan program lain, sehingga membuat siswa 
tertarik dan termotivasi untuk belajar walaupun materi yang dipelajari dirasa susah.

Oleh karena itu media merupakan alat bantu apa saja yang dapat dijadikan sebagai penyalur pesan guna mencapai tujuan pengajaran. Proses belajar mengajar pada hakekatnya adalah proses komunikasi, yaitu proses penyampaian pesan dari sumber pesan melalui saluran/media tertentu ke penerima pesan. Dalam proses belajar mengajar, penggunaan media mempunyai arti yang cukup penting karena dalam kegiatan tersebut ketidakjelasan materi yang disampaikan oleh guru dapat dibantu dengan menghadirkan media sebagai perantara dalam pengajaran. Sebagai alat bantu, media mempunyai fungsi melicinkan jalan menuju tercapainya tujuan pengajaran. Hal ini dilandasi dengan keyakinan bahwa proses belajar mengajar dengan bantuan media akan menghasilkan proses dan hasil belajar yang lebih baik dari pada tanpa bantuan media.

Media Mindjet Managerr 9 merupakan suatu media elektronik yang bersifat multimedia yang mempunyai suatu kelebihan yaitu mengatur informasi dan pola pikir dengan mebentuk peta konsep, dapat membuat data berupa gambar, catatan atau teks, animasi, video serta dapat di link ke program web atau powerpoint. Dalam penyampaian akan terlihat lebih jelas urutan materi pembelajaran yang terstruktur mulai dari konsep yang paling umum kemudian dijelaskan konsep yang lebih mendetail yang dilengkapi visualisasi yang menarik dan dapat meningkatkan motivasi belajar siswa, sehingga dapat mempertinggi kualitas belajar mengajar lebih baik yang kemudian dapat berpengaruh terhadap hasil belajar siswa. Minjet Mindmanager juga dapat membantu siswa dan guru dalam proses pembelajaran di kelas dengan meringkas bahan yang demikian banyak menjadi beberapa lembar ringkasan materi terstruktur yang jauh lebih mudah dapat dipelajari dan diingat oleh siswa (Yoga, 2010).
Mindjet Mindmanagerr adalah sebuah aplikasi software yang member kemudahan dalam hal pembuatan peta pikiran (mind map) sehingga peta pikiran yang dihasilkan mampu memudahkan guru maupun siswa untuk meringkas materi ajar secara efektif dan efisien termasuk dalam hal penyampaian materi ajar sedangkan khusus bagi siswa dapat menyerap materi pelajaran dengan lebih antusias sekaligus mampu memanjakan kesukaan otak siswa dapat mengikuti pelajaran dengan senang dan meningkatkan aktivitas serta hasil belajar siswa itu sendiri (Ibrahim, 2011). Selanjutnya program Mindjet Mindmanagerr dapat dikombinasikan dengan mitode belajar discovery learning.

Guided discovery adalah salah satu bentuk dari metode discovery learning. Discovery learning merupakan salah satu model instruksional kognitif dari Jerome Brunner yang sangat berpengaruh. Menurut Brunner, discovery learning sesuai dengan pencarian pengetahuan secara aktif oleh manusia dan dengan sendirinya memberikan hasil yang baik. Berusaha sendiri untuk mencari pemecahan masalah serta pengetahuan yang menyertainya akan menghasilkan pengetahuan yang bermakna (Trianto, 2007, dalam Sukmana, 2009:1).

Guided discovery merupakan suatu metode pembelajaran yang dirancang untuk mengajarkan konsep-konsep dan hubungan antar konsep (Jacobsen, Eggen, Kauchak, 2009, dalam Marzuqi, 2013:1). Dalam guided discovery siswa diberikan suatu permasalahan untuk dipecahkan dan guru memberikan petunjuk, arahan, umpan balik serta contohcontoh untuk membimbing siswa dalam menyelesaikan masalah tersebut. Selama pembelajaran dengan metode guided discovery, guru masih perlu memberikan susunan (structure) dan bimbingan (guidance) untuk memastikan bahwa abstraksi yang sedang dipelajari sudah akurat dan lengkap. Bimbingan yang diberikan berupa pertanyaan- 
pertanyaan pengarah yang dapat diajukan guru secara langsung maupun melalui berbagai media. Pertanyaan-pertanyaan tersebut harus dapat membimbing dan mengarahkan siswa dalam menemukan konsep yang dipelajari maupun dalam menyelesaikan permasalahan yang dihadapi.

Guided discovery atau penemuan terbimbing merupakan salah satu bentuk metode mengajar yang memungkinkan siswa lebih mampu mengembangkan daya kreativitas dan keinginan-keinginan bergerak yang lebih luas dan bebas sehingga peranan guru dibatasi seminim mungkin, sedangkan siswa diberi kebebasan semaksimal mungkin.

Guru berfungsi sebagai fasilitator dalam guided discovery. Guru bertindak sebagai petunjuk jalan dan membantu siswa agar dapat menggunakan ide, konsep dan keterampilan yang sudah mereka pelajari sebelumnya untuk menemukan pengetahuan baru. Siswa didorong berpikir dan menganalisis sendiri sehingga dapat menemukan prinsip umum berdasarkan bahan atau data yang disediakan.

Pelaksanaan pembelajaran dengan metode ini memang memerlukan waktu yang relatif lama, tetapi jika dilakukan dengan efektif, metode ini cenderung menghasilkan ingatan dan transfer jangka panjang yang lebih baik daripada pembelajaran dengan metode ekspositori (Jacobsen, Eggen, Kauchak, 2009, dalam Marzuqi, 2013:1). Metode guided discovery efektif dalam pembelajaran karena memuat dua kriteria penting dalam pembelajaran aktif, yaitu membangun pengetahuan yang tepat untuk mempermudah pemahaman tentang informasi baru dan menyempurnakan informasi baru dengan dasar pengetahuan yang tepat. Informasi yang diperoleh siswa dapat tertanam dengan baik dan benar. Namun demikian tetap dibutuhkan aktifitas siswa sehingga terjadi kesinambungan dalam proses belajar.

Keaktifan siswa dalam proses pembelajaran akan menyebabkan interaksi yang tinggi antara guru dengan siswa ataupun dengan siswa itu sendiri. Hal ini akan mengakibatkan suasana kelas menjadi segar dan kondusif, dimana masing - masing siswa dapat melibatkan kemampuannya semaksimal mungkin. Aktivitas yang timbul dari siswa akan mengakibatkan pula terbentuknya pengetahuan dan keterampilan yang akan mengarah pada peningkatan prestasi.

Keaktifan siswa selama proses belajar mengajar merupakan salah satu indikator adanya keinginan atau motivasi siswa untuk belajar. Siswa dikatakan memiliki keaktifan apabila ditemukan ciri-ciri perilaku seperti: sering bertanya kepada guru atau siswa lain, mau mengerjakan tugas yang diberikan guru, mampu menjawab pertanyaan, senang diberi tugas belajar, dan lain sebagainya. (Rosalia, 2005:4)

Keaktifan siswa dalam proses pembelajaran akan menyebabkan interaksi yang tinggi antara guru dengan siswa ataupun dengan siswa itu sendiri. Hal ini akan mengakibatkan suasana kelas menjadi segar dan kondusif, dimana masing-masing siswa dapat melibatkan kemampuannya semaksimal mungkin. Aktivitas yang timbul dari siswa akan mengakibatkan pula terbentuknya pengetahuan dan keterampilan yang akan mengarah pada peningkatan prestasi.

\section{METODE}

Pendekatan yang digunakan dalam penelitian ini adalah penelitian tindakan kelas. Menurut Sanjaya (2011:26), penelitian tindakan kelas (PTK) adalah "proses pengkajian masalah pembelajaran di dalam kelas melalui refleksi diri dalam upaya memecahkan masalah belajar dengan cara melakukan berbagai tindakan yang terencana dalam situasi nyata dan menganalisis setiap pengaruh tindakan itu".

Hal ini berkaitan dengan konsep penelitian ini, yaitu menerapkan Guided Discovery dengan menggunakan media 
mindjet mindmanager untuk meningkatkan aktivitas dan hasil belajar kimia siswa. Arifin (2010:75) menguraikan bahwa "PTK termasuk jenis penelitian kualitatif, sehingga analisis datanya bersifat siklus. Analisis siklus PTK meliputi 4 tahap, yaitu: Siklus 1, meliputi: 1) perencanaan, 2) tindakan, 3) observasi, 4) refleksi; Siklus 2, meliputi: 1) perencanaan, 2) tindakan, 3) observasi, 4) refleksi”, sebagaimana gambar berikut:

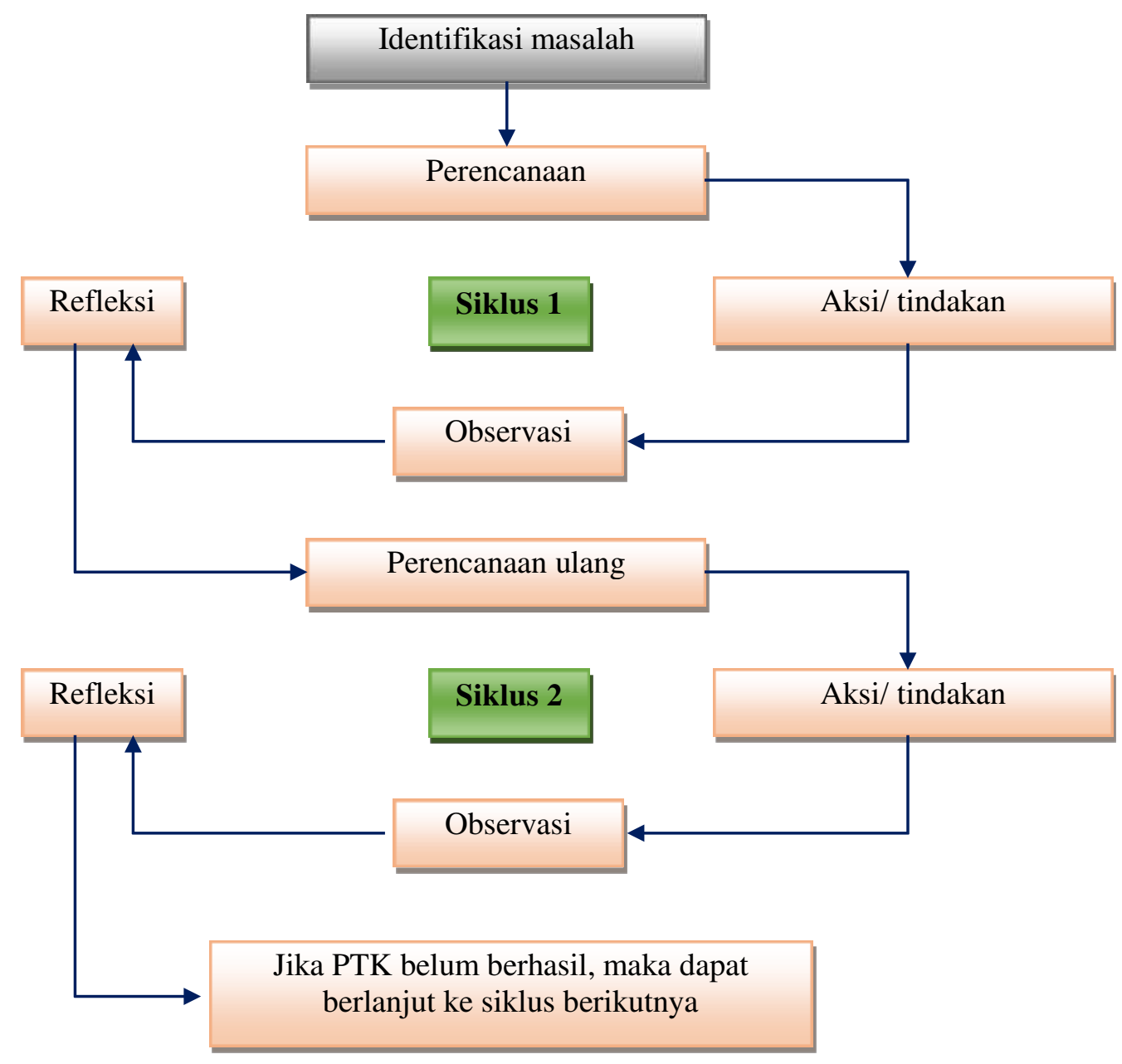

Gambar 3.1 Siklus PTK model Hopkins (Sanjaya, 2011:54)

Sedangkan sumber data dalam penelitian ini adalah siswa kelas X IPA di SMA Bahrul Magfiroh Tahun Pelajaran 2015/2016 sebagai kumpulan individu yang diberikan tindakan dan melaksanakan tes tulis di setiap akhir siklus.

Selanjutnya setelah data diperoleh dari sumber data, dilakukan analisis dengan tujuan untuk mengukur hasil belajar kimia siswa setelah siswa mengalami tindakan pembelajaran kimia melalui penerapan Guided Discovery pada materi larutan elektrolit dan larutan non elektrolit, sehingga diperoleh informasi mengenai perubahan atau peningkatannya. Proses pengambilan data dilakukan melalui tes tulis dengan materi Larutan elektrolit dan larutan non elektrolit.

Teknik analisis data yang digunakan adalah deskriptif persentase. Data-data yang dianalisis meliputi rata-rata nilai tes siswa, ketuntasan belajar individu, dan ketuntasan belajar klasikal. Ketuntasan belajar dalam penelitian ini ditentukan berdasarkan kriteria, sebagai berikut: 
Tabel 3.1 Kriteria Ketuntasan Belajar Siswa

\begin{tabular}{c|c|l}
\hline Tingkat Penguasaan & Nilai Huruf & \multicolumn{1}{|c}{ Keterangan } \\
\hline $85 \leq \mathrm{x}<100$ & A & Sangat Baik \\
\hline $74 \leq \mathrm{x}<84$ & $\mathrm{~B}$ & Baik \\
\hline $64 \leq \mathrm{x}<74$ & $\mathrm{C}$ & Cukup \\
\hline $50 \leq \mathrm{x}<64$ & $\mathrm{D}$ & Kurang \\
\hline $0 \leq \mathrm{x}<50$ & E & Sangat Kurang \\
\hline
\end{tabular}

Sumber: Depdiknas 2004

Adapun untuk menentukan ketuntasan belajar klasikal, maka diukur dengan rumus, sebagai berikut:

$\mathrm{KB}=\frac{\mathrm{fN}}{\sum \mathrm{N}} \times 100 \%$

Keterangan:

$\mathrm{KB}=$ Ketuntasan belajar klasikal

$\mathrm{fN}=$ Jumlah siswa tuntas

$\Sigma \mathrm{N}=$ Jumlah seluruh siswa

Indikator kesuksesan atau keberhasilan penelitian tindakan kelas ini adalah meningkatnya prestasi belajar biologi siswa yang ditunjukkan dengan $80 \%$ dari seluruh siswa memperoleh nilai tes $>65$

\section{HASIL}

Penelitian tindakan ini dilaksanakan di kelas X IPA SMA Bahrul Magfiroh tahun pelajaran 2015/2016 pada tanggal 1-30 Nopember 2015. Proses pembelajaran terbagi menjadi 2 siklus, dimana pembelajaran untuk masing-masing siklus dilaksanakan dalam dua kali tatap muka. Hasil penelitian berupa data aktivitas dan hasil belajar siswa pada setiap siklus. Aktivitas siswa dievaluasi melalaui lembar observasi, sedangkan hasil belajar siswa dievaluasi melalui tes tulis yang dilaksanakan pada akhir siklus. Hasil dari penelitian ini dapat dilihat di bawah ini.

\section{Pra Siklus}

Pra siklus merupakan tahap pengamatan yang peneliti lakukan terhadap subyek penelitian sebelum peneliti melaksanakan penelitian. Diketahui bahwa metode pembelajaran yang selama ini digunakan oleh guru dalam proses belajar mengajar adalah ceramah dengan disertai contohcontoh soal dan cara menjawabnya, sehingga proses pembelajaran hanya menggunakan satu arah yaitu guru yang menjadi satu-satunya sumber belajar dan kurang melibatkan siswa dalam proses mengajar.

Tabel 4.1 Nilai Hasil Belajar Siswa pada Pra siklus

\begin{tabular}{c|l|c|c|c|c}
\hline No & Nama & L & Nilai & \multicolumn{2}{|c}{ Ketuntasan Belajar } \\
\hline 1 & Ahmad Ainun Naim & L & 60 & Th & \\
\hline 2 & Ahmad Sauqi Muabab & L & 75 & & T \\
\hline 3 & Ahmad Wildan Al-Farizy & L & 67 & & T \\
\hline 4 & Ali Mashury & L & 60 & TT & \\
\hline 5 & Febi Setiawan & L & 55 & TT & \\
\hline 6 & Fika Fatul Ula & L & 65 & & T \\
\hline
\end{tabular}




\begin{tabular}{c|l|c|c|c|c}
\hline 7 & Hamdan Fajar H & L & 60 & TT & \\
\hline 8 & Ilham Rizky & L & 75 & & T \\
\hline 9 & Muhammad Asrofi Abdillah & L & 65 & & T \\
\hline 10 & Muhammad Dian Al-gifari & L & 70 & & T \\
\hline 11 & Muhammad Dimiyati & L & 63 & TT & \\
\hline 12 & Muhammad Iqbal Rafi & L & 58 & TT & \\
\hline 13 & Muhammad Lukman & L & 80 & & T \\
\hline 14 & Muhammad Nuril Rosyadi & L & 58 & TT & \\
\hline 15 & Muhammad Robbil M. R & L & 45 & TT & \\
\hline 16 & Rico Fernando & L & 57 & TT & T \\
\hline 17 & Riki Yosan & L & 75 & & T \\
\hline 18 & Sofyan Sauri & L & 64 & TT & T \\
\hline 19 & Taufiq Edvan R & L & 60 & TT & \\
\hline 20 & Yunus Bahtiar & L & 55 & TT & \\
\hline
\end{tabular}

Data-data yang tercantum pada tabel 4.1 di atas menunjukkan hasil belajar kimia siswa kelas X IPA SMA Bahrul Maghfiroh pada pra siklus. Berdasarkan data tersebut selanjutnya dianalisis, sebagai berikut :

Rata - rata $=\frac{\mathrm{fN}}{\sum \mathrm{N}}=\frac{1267}{20}=63,35$

Tabel 4.2 Persentase Ketuntasan klasikal Pra Siklus

\begin{tabular}{|c|c|c|c|c|}
\hline Tingkat Penguasaan & $\mathbf{N}$ & Prosentase & Akumulasi & T/BT \\
\hline $85 \leq x<100$ & 0 & $0 \%$ & $0 \%$ & \multirow[t]{3}{*}{$40 \%$ siswa tuntas } \\
\hline $74 \leq x<84$ & 4 & $20 \%$ & $20 \%$ & \\
\hline $64 \leq x<74$ & 4 & $20 \%$ & $20 \%$ & \\
\hline $50 \leq x<64$ & 11 & $55 \%$ & - & \multirow{2}{*}{$\begin{array}{c}60 \% \text { siswa belum } \\
\text { tuntas }\end{array}$} \\
\hline $0 \leq \mathrm{x}<50$ & 1 & $5 \%$ & - & \\
\hline Total & 20 & $100 \%$ & $40 \%$ & \\
\hline
\end{tabular}

Keterangan : $\mathrm{N}=$ Jumlah siswa

Hasil analisis data di atas menunjukkan bahwa nilai rata-rata hasil belajar kimia siswa kelas $\mathrm{X}$ IPA SMA Bahrul Maghfiroh pada pra siklus adalah 63,35 dengan predikat kurang.

$$
\begin{aligned}
\mathrm{TT} & =\text { Belum tuntas } \\
\mathrm{T} & =\text { Tuntas }
\end{aligned}
$$

\section{Hasil observasi aktivitas guru}

Tabel 4.3. Hasil Observasi Aktivitas Guru Dalam Kegiatan Belajar Mengajar

\begin{tabular}{l|l|c|c}
\hline \multirow{2}{*}{ Tahap } & \multicolumn{1}{c|}{ Indikator } & \multicolumn{2}{c}{ Skor } \\
Kegiatan & \multicolumn{1}{c}{ Siklus } & Siklus \\
& & 1 & 2 \\
\hline Kegiatan & 1. Membuka pelajaran dengan salam & 4 & 4 \\
awal & 2. Mengecek kehadiran siswa & 4 & 4 \\
& 3. Member apersepsi dan motivasi kepada siswa & 2 & 3
\end{tabular}




\begin{tabular}{l|l|c|c}
\hline Kegiatan & $\begin{array}{l}\text { 1. Menginformasikan tujuan pembelajaan } \\
\text { Inti }\end{array}$ & 3 & 4 \\
& $\begin{array}{l}\text { 2. Menyampaikan langkah-langkah model } \\
\text { pembelajaran Guided Discovery dengan } \\
\text { menggunakan media mindjet Mindmanager } \\
\text { 3. Memperkenalkan materi larutan elektrolit dan non } \\
\text { elektrolit kepada siswa }\end{array}$ & 3 & 4 \\
& $\begin{array}{l}\text { 4. Melibatkan siswa secara aktif dalam setiap kegiatan } \\
\text { pembelajaran }\end{array}$ & 1 & 3 \\
& $\begin{array}{l}\text { 5. Membagi siswa dalam kelompok } \\
\text { 6. Membimbing siswa dalam melakukan diskusi }\end{array}$ & 3 & 3 \\
& $\begin{array}{l}\text { 7. Membimbing siswa mempresentasikan hasil diskusi } \\
\text { 8. Mendiskusikan hasil pembelajaran }\end{array}$ & 2 & 3 \\
& 9. Melakukan Tanya jawab dengan siswa & 1 & 3 \\
\hline Kegiatan & 1. Membuat rangkuman/simpulan pelajaran & 2 & 3 \\
\hline Akhir & 2. Mengevaluasi kegiatan pembelajaran & 3 & 3 \\
& 3. Melakukan refleksi & 1 & 2 \\
& 4. Menutup pelajaran dengan salam & 4 & 4 \\
\hline
\end{tabular}

Tabel di atas jumlah skor akhir kemampuan guru untuk menerapkan Model Pembelajaran Guided Discovery dengan menggunakan Media Mindjet Mindmanager untuk meningkatkan aktivitas dan hasil belajar Kimia siswa kelas X IPA SMA Bahrul Maghfiroh Malang pada siklus I adalah 39 dari jumlah skor maksimal 68. Prosentase indicator yang berhasil dicapai guru pada siklus 1 adalah 57,35\%. Pencapaian pada siklus 2 adalah 52 dari jumlah skor maksimal 68 . Prosentase indicator yang dicapai pada siklus 2 adalah 76,47\%. Kenaikan prosentase dari siklus 1 ke siklus 2 adalah 19,12\%.

\section{Hasil observasi aktivitas siswa}

Pengamatan terhadap aktivitas belajar siswa dilaksanakan selama KBM berlangsung. Berikut hasil observasi aktivitas siswa dalam pembelajaran siklus 1 .

Tabel 4.4 Observasi Aktivitas Siswa dalam KBM siklus I

\begin{tabular}{c|l|c|c|c} 
No & \multicolumn{1}{|c|}{$\begin{array}{c}\text { Aktivitas yang Diamati } \\
\text { siswa aktif }\end{array}$} & $\begin{array}{c}\text { Prosentase } \\
(\%)\end{array}$ & Skor \\
\hline 1. & Perhatian tehadap penjelasan guru & 12 & 60 & 3 \\
\hline 2. & Keberanian bertanya & 5 & 20 & 1 \\
\hline 3. & Kemampuan menjawab pertanyaan & 2 & 10 & 1 \\
\hline 4. & Keberanian mengemukakan ide-ide & 13 & 65 & 3 \\
\hline 5. & Peran aktif dalam kelompok belajar & 11 & 55 & 2 \\
\hline 6. & Sikap belajar dalam kelompok & 9 & 45 & 2 \\
\hline 7. & Kemampuan mempresentasikan hasil & 12 & 60 & 3 \\
\hline 8. & Kemampuan merumuskan kesimpulan & 10 & 50 & 2
\end{tabular}




\begin{tabular}{l|l|c|c|c}
\hline 10. & Pengerjaan tugas secara mandiri & 6 & 30 & 1 \\
\hline Rata-rata & 8,4 & $42 \%$ & 1,9 \\
\hline & Predikat & & Kurang & \\
\hline
\end{tabular}

Ketērängan skor: 1=kurang, 2=cukup, 3=baik, 4=sangat baik

Tabel 4.5 Observasi Aktivitas Siswa dalam KBM siklus 2

\begin{tabular}{c|l|c|c|c}
\hline No & \multicolumn{1}{|c|}{ Aktivitas yang Diamati } & $\begin{array}{c}\text { Frekunsi } \\
\text { siswa aktif }\end{array}$ & $\begin{array}{c}\text { Prosentase } \\
(\%)\end{array}$ & Skor \\
\hline 1. & Perhatian tehadap penjelasan guru & 19 & 95 & 4 \\
\hline 2. & Keberanian bertanya & 13 & 65 & 3 \\
\hline 3. & Kemampuan menjawab pertanyaan & 8 & 60 & 2 \\
\hline 4. & Keberanian mengemukakan ide-ide & 19 & 95 & 2 \\
\hline 5. & Peran aktif dalam kelompok belajar & 13 & 65 & 3 \\
\hline 6. & Sikap belajar dalam kelompok & 19 & 95 & 4 \\
\hline 7. & Kemampuan mempresentasikan hasil & 20 & 100 & 4 \\
\hline 8. & Kemampuan merumuskan kesimpulan & 19 & 95 & 4 \\
\hline 9. & Semangat siswa & 12 & 60 & 2 \\
\hline 10. & Pengerjaan tugas secara mandiri & 15,5 & $77 \%$ & 3,2 \\
\hline & Rata-rata & & Baik &
\end{tabular}

Keterangan skor: $1=$ =kurang, $2=$ cukup, $3=$ =baik, $4=$ =sangat baik

Berdasarkan hasil observasi aktivitas siswa dalam kegiatan belajar dan mengajar pada siklus 1 dan siklus 2 mengalami kenaikan sebesar $35 \%$ dari predikat Kurang menjadi Baik.

\section{Analisa Data dan refleksi}

Tabel 4.6. Hasil Belajar siswa pada siklus 1

\begin{tabular}{c|l|c|c|c|c}
\hline \multirow{2}{*}{ No } & \multicolumn{1}{|c|}{ Nama } & L & Nilai & \multicolumn{2}{|c}{ Ketuntasan Belajar } \\
\hline 1 & & Ahmad Ainun Naim & Belum Tuntas & Tuntas \\
\hline 2 & Ahmad Sauqi Muabab & L & 78 & & $\mathrm{~T}$ \\
\hline 3 & Ahmad Wildan Al-Farizy & $\mathrm{L}$ & 70 & & $\mathrm{~T}$ \\
\hline 4 & Ali Mashury & $\mathrm{L}$ & 65 & & $\mathrm{~T}$ \\
\hline 5 & Febi Setiawan & $\mathrm{L}$ & 60 & $\mathrm{TT}$ & $\mathrm{T}$ \\
\hline 6 & Fika Fatul Ula & $\mathrm{L}$ & 69 & & $\mathrm{~T}$ \\
\hline 7 & Hamdan Fajar H & $\mathrm{L}$ & 62 & $\mathrm{TT}$ & \\
\hline 8 & Ilham Rizky & $\mathrm{L}$ & 77 & & $\mathrm{~T}$ \\
\hline 9 & Muhammad Asrofi Abdillah & $\mathrm{L}$ & 70 & & $\mathrm{~T}$ \\
\hline 10 & Muhammad Dian Al-gifari & $\mathrm{L}$ & 75 & & $\mathrm{~T}$ \\
\hline 11 & Muhammad Dimiyati & $\mathrm{L}$ & 64 & $\mathrm{TT}$ & \\
\hline 12 & Muhammad Iqbal Rafi & $\mathrm{L}$ & 63 & $\mathrm{TT}$ & \\
\hline 13 & Muhammad Lukman & $\mathrm{L}$ & 83 & & $\mathrm{~T}$ \\
\hline 14 & Muhammad Nuril Rosyadi & $\mathrm{L}$ & 60 & $\mathrm{TT}$ & \\
\hline
\end{tabular}




\begin{tabular}{c|l|c|c|c|c}
\hline 15 & Muhammad Robbil Masdar R & L & 59 & TT & \\
\hline 16 & Rico Fernando & L & 64 & TT & T \\
\hline 17 & Riki Yosan & L & 78 & & T \\
\hline $18-$ & Sofyan Sauri & L & 68 & & T \\
\hline 19 & Taufiq Edvan R & L & 60 & TT & \\
\hline 20 & Yunus Bahtiar & L & 55 & TT & \\
\hline & Jumlah & & 1347 & 7 & 13 \\
\hline
\end{tabular}

Data-data yang tercantum pada tabel $4.6 \mathrm{di}$ atas menunjukkan hasil belajar kimia siswa kelas X IPA SMA Bahrul Maghfiroh pada pra siklus. Berdasarkan data tersebut selanjutnya dianalisis, sebagai berikut:
Rata - rata $=\frac{\mathrm{fN}}{\sum \mathrm{N}}=\frac{1347}{20}=67,35$

Hasil analisis data di atas menunjukkan bahwa nilai rata-rata hasil belajar kimia siswa kelas $\mathrm{X}$ IPA SMA Bahrul Maghfiroh pada pra siklus adalah 67,35 dengan predikat cukup.

Tabel 4.7 Persentase Ketuntasan klasikal Siklus 1

\begin{tabular}{|c|c|c|c|c|}
\hline Tingkat Penguasaan & N & Prosentase & Akumulasi & \multicolumn{1}{|c|}{ T/TT } \\
\hline $85 \leq \mathrm{x}<100$ & 0 & $0 \%$ & $0 \%$ & $60 \%$ siswa \\
\hline $74 \leq \mathrm{x}<84$ & 5 & $25 \%$ & $25 \%$ & tuntas \\
\hline $64 \leq \mathrm{x}<74$ & 7 & $35 \%$ & $35 \%$ & \\
\hline $50 \leq \mathrm{x}<64$ & 8 & $40 \%$ & - & $40 \%$ siswa \\
$0 \leq \mathrm{x}<50$ & 0 & $0 \%$ & - & belum tuntas \\
\hline Total & 20 & $100 \%$ & $40 \%$ & \\
\hline Predikat & & & Cukup & \\
\hline
\end{tabular}

Tabel 4.8. Hasil Belajar Siswa pada Siklus 2

\begin{tabular}{|c|c|c|c|c|c|}
\hline \multirow[b]{2}{*}{ No } & \multirow[b]{2}{*}{ Nama } & \multirow[b]{2}{*}{$\mathrm{L}$} & \multirow[b]{2}{*}{ Nilai } & \multicolumn{2}{|c|}{ Ketuntasan Belajar } \\
\hline & & & & $\begin{array}{l}\text { Belum } \\
\text { Tuntas }\end{array}$ & Tuntas \\
\hline 1 & Ahmad Ainun Naim & $\mathrm{L}$ & 75 & & $\mathrm{~T}$ \\
\hline 2 & Ahmad Sauqi Muabab & $\mathrm{L}$ & 80 & & $\mathrm{~T}$ \\
\hline 3 & Ahmad Wildan Al-Farizy & $\mathrm{L}$ & 75 & & $\mathrm{~T}$ \\
\hline 4 & Ali Mashury & $\mathrm{L}$ & 70 & & $\mathrm{~T}$ \\
\hline 5 & Febi Setiawan & $\mathrm{L}$ & 70 & & $\mathrm{~T}$ \\
\hline 6 & Fika Fatul Ula & $\mathrm{L}$ & 75 & & $\mathrm{~T}$ \\
\hline 7 & Hamdan Fajar H & $\mathrm{L}$ & 75 & & $\mathrm{~T}$ \\
\hline 8 & Ilham Rizky & $\mathrm{L}$ & 77 & & $\mathrm{~T}$ \\
\hline 9 & Muhammad Asrofi Abdillah & $\mathrm{L}$ & 80 & & $\mathrm{~T}$ \\
\hline 10 & Muhammad Dian Al-gifari & $\mathrm{L}$ & 75 & & $\mathrm{~T}$ \\
\hline 11 & Muhammad Dimiyati & $\mathrm{L}$ & 75 & & $\mathrm{~T}$ \\
\hline 12 & Muhammad Iqbal Rafi & $\mathrm{L}$ & 78 & & $\mathrm{~T}$ \\
\hline 13 & Muhammad Lukman & $\mathrm{L}$ & 85 & & $\mathrm{~T}$ \\
\hline 14 & Muhammad Nuril Rosyadi & $\mathrm{L}$ & 78 & & $\mathrm{~T}$ \\
\hline 15 & Muhammad Robbil Masdar R & $\mathrm{L}$ & 75 & & $\mathrm{~T}$ \\
\hline
\end{tabular}




\begin{tabular}{c|l|c|c|c|c}
\hline 16 & Rico Fernando & L & 70 & & T \\
\hline 17 & Riki Yosan & L & 80 & & T \\
\hline 18 & Sofyan Sauri & L & 74 & & T \\
\hline 19 & Taufiq Edvan R & L & 65 & & T \\
\hline 20 & Yunus Bahtiar & L & 62 & TT & \\
\hline & Jumlah & & 1494 & 1 & 19 \\
\hline
\end{tabular}

Data-data yang tercantum pada tabel 4.8 di atas menunjukkan hasil belajar kimia siswa kelas X IPA SMA Bahrul Maghfiroh pada siklus 2. Berdasarkan data tersebut selanjutnya dianalisis, sebagai berikut :

$$
\text { Rata }- \text { rata }=\frac{\mathrm{fN}}{\sum \mathrm{N}}=\frac{1494}{20}=74,7
$$

Hasil analisis data di atas menunjukkan bahwa nilai rata-rata hasil belajar kimia siswa kelas $\mathrm{X}$ IPA SMA Bahrul Maghfiroh pada pra siklus adalah 74,7 dengan predikat baik.

Tabel 4.9 Persentase Ketuntasan klasikal Siklus 2

\begin{tabular}{c|c|c|c|c}
\hline Tingkat Penguasaan & N & Prosentase & Akumulasi & \multicolumn{1}{|c}{ T/TT } \\
\hline $85 \leq \mathrm{x}<100$ & 1 & 5 & 5 & $95 \%$ siswa \\
\hline $74 \leq \mathrm{x}<84$ & 13 & 65 & 65 & tuntas \\
\hline $64 \leq \mathrm{x}<74$ & 5 & 25 & 25 & \\
\hline $50 \leq \mathrm{x}<64$ & 1 & 5 & 5 & $5 \%$ siswa \\
belum tuntas
\end{tabular}

\section{PEMBAHASAN}

Penampilan guru dalam pembelajaran kimia melalui penerapan model pembelajaran Guided Discovery dengan menggunakan Media Mindjet Mindmanager untuk meningkatkan aktivitas dan hasil belajar Kimia siswa kelas X IPA SMA Bahrul Maghfiroh Malang sangat baik. Hasil observasi aktivitas guru dalam pembelajaran menunjukkan sebagian besar indicator pengamatan telah mencapai nilai maksimal, dimana terdapat enam indicator yang mendapatkan nilai 4 dan delapan indicator mendapat nilai tiga, sedangkan 2 indikator mendapatkan nilai dua, dan satu indicator mendapatkan nilai satu. Hal ini menunjukkan indicator dalam observasi telah secara maksimal dilakukan.

Berdasarkan hasil observarsi aktivitas siswa dari siklus 1 ke siklus 2 siswa semakin aktif dalam pembelajaran. Banyak siswa yang semakin berani mengemukakan pertanyaanpertanyaan kepada guru dan menjawab pertanyaan, serta mayoritas siswa sudah mampu menyelesaikan tugas-tugas yang diberikan. Siswa sudah berani mengemukakan ide-ide konsep menuangkan ke media pembelajaran.

Tabel 4.10. Perbandingan Hasil Observasi aktivitas siswa

\begin{tabular}{c|c|c|c}
\hline Siklus & Frekuensi & Prosentase & Skor \\
\hline 1 & 8,4 & $42 \%$ & 1,9 (Kurang) \\
\hline 2 & 15,5 & $77 \%$ & 3,2 (Baik) \\
\hline Kenaikan aktivitas dari siklus 1 ke siklus 2 & 7,1 & $35 \%$ & 2,2 \\
\hline
\end{tabular}


Berdasarkan hasil evaluasi siswa, peneliti mereflesi bahwa hasil pembelajaran menerapkan Model Pembelajaran Guided Discovery dengan menggunakan Media Mindjet Mindmanager untuk meningkatkan aktivitas dan hasil belajar Kimia siswa kelas X
IPA SMA Bahrul Maghfiroh Malang berhasil dengan baik dan terbukti mampu meningkatkan hasil belajar siswa. Berdasarkan hasil tes yang dilaksanakan pada pra siklus dan pada akhir siklus pembelajaran.

Tabel 4.11. Perbandingan nilai Pra siklus ke tindakan siklus 1 dan siklus 2

\begin{tabular}{c|l|c|c|c} 
No & \multicolumn{1}{|c|}{ Perbandingan } & $\begin{array}{c}\text { Pra } \\
\text { siklus }\end{array}$ & $\begin{array}{c}\text { Siklus } \\
\mathbf{1}\end{array}$ & $\begin{array}{c}\text { Siklus } \\
\mathbf{2}\end{array}$ \\
\hline 1. & Rata-rata nilai siswa & 63,35 & 67,35 & 76,1 \\
\hline 2. & Ketuntasan belajar & $40 \%$ & $60 \%$ & $95 \%$ \\
\hline 3. & $\begin{array}{l}\text { Peningkatan prosentase ketuntasan belajar dari pra } \\
\text { siklus ke siklus 1 }\end{array}$ & $40 \%$ & \\
\hline 4. & $\begin{array}{l}\text { Peningkatan prosentase ketuntasan belajar dari siklus } \\
\text { 1 ke siklus 2 }\end{array}$ & & $35 \%$ \\
\hline 5. & $\begin{array}{l}\text { Peningkatan prosentase ketuntasan belajar dari pra } \\
\text { siklus ke siklus 2 }\end{array}$ & & $45 \%$ \\
\hline
\end{tabular}

Dengan grafik

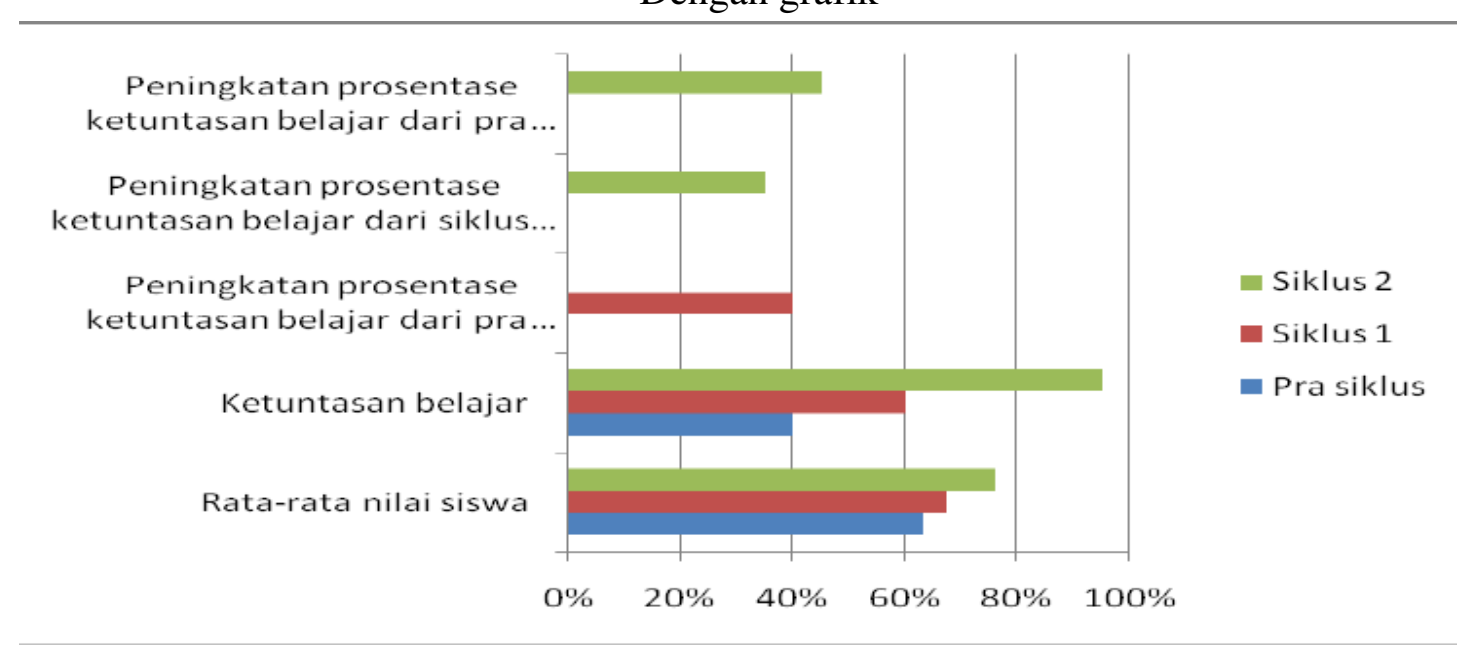

\section{KESIMPULAN DAN SARAN}

Penerapan model pembelajaran Guided Discovery dengan menggunakan Media Mindjet Mindmanager untuk meningkatkan aktivitas dan hasil belajar Kimia siswa kelas X IPA SMA Bahrul Maghfiroh Malang. Hal tersebut dibuktikan dari:

1. Frekuensi Aktivitas siswa pada siklus 1 sebesar 8,1 dengan prosentase sebesar $42 \%$, siklus 2 frekuensi aktivitas siswa sebesar 15,5 dengan prosentase sebesar 77 $\%$.

2. Rata -rata nilai tes siswa pada pra siklus adalah 63,35, selanjutnya meningkat menjadi 67,35 meningkatkan menjadi pada siklus 2 mencapai 76,1 .

3. Prosentase ketuntasan belajar klasikal pada pra siklus hanya $40 \%$ selanjutnya meningkat $60 \%$ menjadi pada siklus 1 , dan prosentase ketuntasan belajar klasikal pada siklus 2 mencapai $95 \%$. 


\section{DAFTAR RUJUKAN}

Asnawir. 2004. Media Pembelajaran. Jakarta: Ciputat Press

Arsyad, Azhar. 2007. Media Pembelajaran. Jakarta: Raja Grafindo Persada.

Arifin. 2010. Penelitian Pendidikan: Pendekatan Kuantitatif \& Kualitatif. Yogyakarta: Lilin Persada Press.

Bagus,Ida dkk. (2007). Penggunaan Model Siklus Belajards Pean Peta Konsep Untuk Meningkatkan Kualitas Pembelajaran Sains/Kimia di SMPN 8 Malang.Naskah disampaikan sebagai acuan pada pendidikan dan Latihan Profesi Guru (PLPG) di PSG Rayon15 Universitas Negeri Malang

Dimyati dan Mudjiono. 2013. Belajar dan Pembelajaran. Cetakan Kelima, Februari 2013. Jakarta: Rineka Cipta.

Hamalik, Oemar. 2013. Proses Belajar Mengajar. Cetakan Kelima Belas, April 2013. Jakarta: PT. Bumi Aksara.

Irawan, Yudi. 2012. Konsep Belajar dan Pembelajaran. (Online), (http://almuroqobah.blogspot.com), diakses 9 Februari 2015.

Istiqomah, Fatih. 2014. Penerapanan Model

Guided Discovery Learning untuk Meningkatkan Motivasi dan Hasil Belajar Siswa. Jurnal Ilmu Pendidikan FKIP Universitas Lampung, (Online), (http://www.jurnal.fkip.unila.ac.id), diakses 11 Maret 2015.

Khairudin, Nanag. Pengembangan Media Pembelajaran dengan menggunakan Aplikasi Minjet Mindmanager 9 Untuk Siswa SMA pada Pokok Bahasan Alat Optik, Vol.1 No. 1 April 2013 Jurusan Pendidikan Fisika Universitas Negeri Surakarta
Marzuqi, Mohammad. 2013. Metode Pembelajaran Guided Discovery. (Online), (http://matematicedu.blogspot.com/2013/01/metodepembelajaran-guided-discovery.html), diakses 7 Maret 2015.

Munawar, Indra. 2009. Hasil Belajar (Pengertian dan Definisi). (Online), (http:// indramunawar.blogspot.com/2009/hasilbelajar-pengertian-\&-definisi.html), diakses 16 Februari 2015.

Sanjaya, Wina. 2011. Penelitian Tindakan Kelas. Edisi Pertama. Cetakan ke-3. Jakarta: Kencana Prenada Media Group.

Sukesih, Esih. 2013. Pengertian Hasil Belajar. (Online), (http://esihkeyc.blogspot.com), diakses 10 Maret 2015.

Sukmana, Prasetya Budi. 2009. Model Pembelajaran Guided Discovery (penemuan terbimbing). (Online), (https://prasetyabudisukmana.wordpress. com/2009/07/22/model-pembelajaranguided-discovery-pennemuan-terbimbing), diakses 7 Maret 2015.

Sumoharjo, Addy. 2011. Definisi Konsep Hasil Belajar. (Online), (http://addyarchy07.blogspot.com), diakses 12 Februari 2015.

Wardhani, Dyah Ayu Pramoda. 2013. Penerapan Pembelajaran Kooperatif dengan Metode Guided Discovery untuk Meningkatkan Keaktifan Belajar Siswa pada Pokok Bahasan Segitiga dan Segi Empat Kelas VII-B SMP Negeri 2 Kepanjen. Jurnal Penelitian Pendidikan Universitas Negeri Malang, (Online), (http://www.jurnal-online.um.ac.id), diakses 7 Maret 2015.

Yoga, Djohan. 2010. Petunjuk Praktis Untuk Menerapkan Kegiatan Belajar Mengajar Berbasis Mind Map. Diakses pada tanggal 03 Januari 2013. 